\title{
Pathological complications of non-survivors of newborn extracorporeal membrane oxygenation
}

\author{
Margaret J Evans, Pat A McKeever, G A Pearson, D Field, R K Firmin
}

\begin{abstract}
The pathology was reviewed of the early deaths identified from the first $\mathbf{5 0}$ neonates treated with extracorporeal membrane oxygenation (ECMO) during its introduction to the UK. Fifteen neonates died during or shortly after ECMO between August 1989 and June 1992. Data on 12 are presented (three did not have a postmortem examination). The clinical diagnoses at referral for ECMO were as follows: persistent pulmonary hypertension of the newborn (six infants), primary congenital pneumonia (one infant), community acquired pneumonia (two infants), birth asphyxia (one infant), respiratory distress syndrome (one infant), and meconium aspiration syndrome (one infant). In our group, at necropsy, five had significant haemorrhage (three intracranial, one pulmonary, one pericardial and intraventricular). Three of five infants with evidence of haemorrhage also had signs of sepsis. Six infants had evidence at necropsy of systemic sepsis, five showed evidence of severe anoxic brain injury, and four infants had cerebellar haemorrhages. Three infants had evidence of myocardial ischaemia. It is difficult to discriminate between the relative influence of the primary diagnosis, the mode of treatment, and the severity of presentation in the genesis of this pathology. It is likely that the extent and severity of some of the findings represent a pathological progression that would have been interrupted by the death of the patient, had ECMO not been instituted. (Arch Dis Child 1994; 71: F88-F92)
\end{abstract}

Department of Histopathology, Leicester Royal Infirmary, Leicester $M$ J Evans

P A McKeever

Department of Paediatric Cardiology, Groby Road Hospital, Leicester

G A Pearson

$D$ Field

R K Firmin

Correspondence to: Dr $M J$ Evans, Department of Pathology, University of Aberdeen, University Medical Buildings,

Foresterhill, Aberdeen

AB9 2ZD.

Accepted 26 April 1994
Extracorporeal membrane oxygenation $(E C M O)^{12}$ can be used as a temporary supportive measure for patients with severe respiratory or cardiac disease. It was first used successfully in an adult in $1972,{ }^{3}$ but in the past 15 years it has been used extensively, mainly in the USA, as a standard treatment in neonatal intensive care. At Groby Road Hospital, Leicester, an ECMO service has been available in the UK. ${ }^{4}$ This programme treated 77 patients over the period August 1989 to June 1992 , of whom 50 were neonates. Thirty five $(70 \%)$ of these 50 survived the presenting illness. We carried out a pathological review of 12 of the 15 who died during or shortly after ECMO (three did not have a postmortem examination). We present an overview of the pathological changes that were found.

\section{Patients and methods}

Table 1 summarises the accepted guidelines ${ }^{1}$ by which the 50 neonates were recruited. Numerical indices of disease severity were used to identify infants who were sufficiently ill to warrant ECMO. The required values were drawn from experience in the USA. In practice, however, these values had often been far exceeded at the point of referral and the patients were referred when their doctors felt that conventional treatment had little more to contribute. ${ }^{5}$

Precise details about the techniques used in establishing and maintaining extracorporeal life support have been detailed elsewhere. ${ }^{12}$ In summary, the patient receives a venoarterial cannulation for cardiopulmonary support or a venovenous cannulation for support purely with gas exchange. In the neonatal age group, venoarterial cannulation is achieved surgically from a cervical approach and uses the right internal jugular vein and common carotid artery. Venovenous cannulation is achieved using a 14 French gauge double lumen cannula inserted in the right internal jugular vein. Blood drains from the venous cannula to a small reservoir or 'bladder', from which it is drawn and pumped through a membrane oxygenator, where gas exchange takes place. Before being returned to the patient the blood passes through a heat exchanger. As pulmonary function improves the rate of blood flow through the circuit is reduced in accordance with estimates of the adequacy of tissue oxygen delivery. Finally, when ECMO support is no longer required, the patient is decannulated, sometimes with repair of the vascular access site(s).

During ECMO, modest anticoagulation was achieved with heparin. The whole blood activated clotting time was maintained between 160 and 200 seconds, and platelet consumption within the circuit was compensated by regular transfusion. Daily cranial and cardiac ultrasound examinations formed part of the clinical monitoring.

\section{Table 1 Selection criteria for neonatal ECMO}

\section{Gestational age $>34$ weeks}

Birth weight $>2000 \mathrm{~g}$

Ventilated for $<10$ days

No intraventricular haemorrhage

Oxygenation index (mean arterial pressure $\times \mathrm{FIO}_{2}(\%) /$

postductal oxygen tension $(\mathrm{mm} \mathrm{Hg}))>40$ or intractable carbon dioxide retention

Treatable primary diagnosis 
Table 2 Characteristics of all neonates undergoing ECMO

\begin{tabular}{|c|c|c|c|c|c|c|}
\hline $\begin{array}{l}\text { Patient } \\
\text { No }\end{array}$ & Sex & $\begin{array}{l}\text { Birth weight } \\
\text { (g) }\end{array}$ & $\begin{array}{l}\text { Age at referral } \\
\text { (hours) }\end{array}$ & $\begin{array}{l}\text { Oxygen } \\
\text { index }\end{array}$ & $\begin{array}{l}\text { Duration of } \\
\text { ECMO (hours) }\end{array}$ & $\begin{array}{l}\text { Mode of } \\
\text { cannulation }\end{array}$ \\
\hline 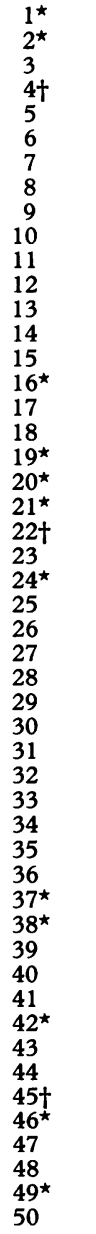 & 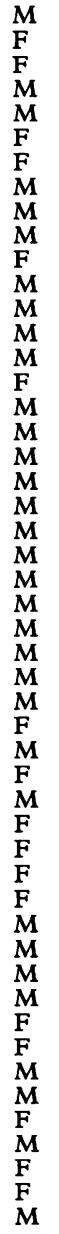 & $\begin{array}{l}4070 \\
4200 \\
3990 \\
3000 \\
3100 \\
3740 \\
3360 \\
2700 \\
2690 \\
3600 \\
2440 \\
3660 \\
2600 \\
3320 \\
2400 \\
4300 \\
3400 \\
3000 \\
2800 \\
2900 \\
2500 \\
3670 \\
3340 \\
2620 \\
4200 \\
2880 \\
2880 \\
3280 \\
3600 \\
3070 \\
3900 \\
2900 \\
3700 \\
3700 \\
2900 \\
2900 \\
3300 \\
4000 \\
4200 \\
3400 \\
3000 \\
1800 \\
3600 \\
3600 \\
3500 \\
3800 \\
3100 \\
3200 \\
2520 \\
4500\end{array}$ & 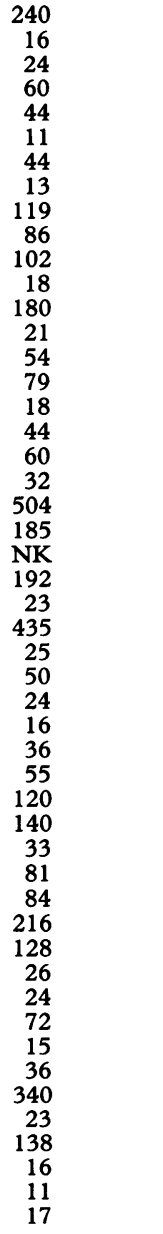 & $\begin{array}{c}\text { NK } \\
132 \cdot 0 \\
83 \cdot 0 \\
112 \cdot 0 \\
58 \cdot 0 \\
55 \cdot 0 \\
47 \cdot 0 \\
64 \cdot 0 \\
\text { NK } \\
63 \cdot 5 \\
51 \cdot 0 \\
68 \cdot 0 \\
70 \cdot 0 \\
61 \cdot 0 \\
77 \cdot 0 \\
42 \cdot 0 \\
55 \cdot 0 \\
\text { NK } \\
131 \cdot 0 \\
\text { NK } \\
116 \cdot 0 \\
\text { NK } \\
\text { NK } \\
36 \cdot 0 \\
96 \cdot 0 \\
\text { NK } \\
29 \cdot 0 \\
233 \cdot 0 \\
\text { NK } \\
82.0 \\
57 \cdot 0 \\
\text { NK } \\
120 \cdot 0 \\
34 \cdot 0 \\
35 \cdot 0 \\
38 \cdot 0 \\
49 \cdot 0 \\
159 \cdot 0 \\
41 \cdot 0 \\
40 \cdot 0 \\
54 \cdot 0 \\
\text { NK } \\
55 \cdot 0 \\
\text { NK } \\
67 \cdot 0 \\
155 \cdot 0 \\
36 \cdot 0 \\
58 \cdot 0 \\
87 \cdot 0 \\
53 \cdot 0\end{array}$ & $\begin{array}{r}130 \\
120 \\
57 \\
115 \\
43 \\
100 \\
71 \\
45 \\
91 \\
222 \\
202 \\
36 \\
240 \\
59 \\
125 \\
188 \\
159 \\
85 \\
58 \\
310 \\
135 \\
144 \\
87 \\
72 \\
93 \\
123 \\
171 \\
256 \\
112 \\
54 \\
101 \\
50 \\
55 \\
61 \\
45 \\
131 \\
405 \\
187 \\
82 \\
97 \\
135 \\
57 \\
151 \\
55 \\
110 \\
250 \\
87 \\
68 \\
158 \\
102\end{array}$ & $\begin{array}{l}\text { VA } \\
\text { VV } \\
\text { VV } \\
\text { VV } \\
\text { VV } \\
\text { VA } \\
\text { VA } \\
\text { VV } \\
\text { VA } \\
\text { VA } \\
\text { VV } \\
\text { VA } \\
\text { VA } \\
\text { VV } \\
\text { VV } \\
\text { VV } \\
\text { VV } \\
\text { VA } \\
\text { VA } \\
\text { VA } \\
\text { VA } \\
\text { VA } \\
\text { VA } \\
\text { VA } \\
\text { VA } \\
\text { VA } \\
\text { VA } \\
\text { VA } \\
\text { VV } \\
\text { VA } \\
\text { VA } \\
\text { VV } \\
\text { VV } \\
\text { VV } \\
\text { VV-VA }\end{array}$ \\
\hline
\end{tabular}

$\mathrm{VA}=$ venoarterial; $\mathrm{VV}=$ venovenous; $\mathrm{NK}=$ not known.

$\star$ Death during/shortly after ECMO. Necropsy performed.

tDeath during/shortly after ECMO. Necropsy not performed.

\section{Results}

Table 2 gives the characteristics of the first 50 neonates treated by ECMO. The infants who died were not significantly different from the population of neonates treated with ECMO as a whole in terms of descriptive data. The gestational ages ranged from 35 to 42 weeks. Birth weights were between $1800 \mathrm{~g}$ and $4300 \mathrm{~g}$ (mean $3290 \mathrm{~g}$ ) and indices of disease severity at referral were not significantly different from those who survived to discharge from Leicester. Two of the neonates were siblings. Ten of the neonates entered the ECMO

Table 3 Characteristics of neonates dying during or shortly after ECMO

\begin{tabular}{llll}
\hline $\begin{array}{l}\text { Patient } \\
\text { No }\end{array}$ & Primary diagnosis & $\begin{array}{c}\text { Pre-ECMO } \\
\text { arterial } p H\end{array}$ & Cause of death \\
\hline 1 & PFC & $7 \cdot 35$ & Massive pulmonary haemorrhage \\
2 & PFC, MAS & $6 \cdot 70$ & Multisystem failure \\
16 & PFC & $7 \cdot 20$ & Persistent pulmonary hypertension \\
19 & Birth asphyxia & $7 \cdot 28$ & Extensive cerebral ischaemia \\
20 & ?Congenital pneumonia, PFC & $7 \cdot 40$ & PFC \\
21 & Pneumococcal pneumonia & $7 \cdot 16$ & Massive haemorrhage, sepsis \\
24 & PFC & $7 \cdot 60$ & PFC \\
37 & PFC & $7 \cdot 39$ & Cerebral ischaemia \\
38 & Viral pneumonia & $7 \cdot 13$ & Renal failure, extensive pulmonary disease \\
42 & RDS & $7 \cdot 25$ & Cerebellar haemorrhage \\
46 & PFC, MAS & $6 \cdot 88$ & Massive cerebral haemorrhage and infarc- \\
49 & PFC & $7 \cdot 20$ & tion; septicaemia \\
& & & PFC \\
\hline
\end{tabular}

$\mathrm{PFC}=$ persistent fetal circulation; $\mathrm{MAS}=$ meconium aspiration syndrome; and $\mathrm{RDS}=$ respiratory distress syndrome. programme in the early neonatal period for disorders noted at birth, which did not respond to conventional treatment. Two had been discharged home and were readmitted at eight and 17 days with viral pneumonia and. pneumococcal septicaemia respectively. Again, ECMO was instituted when they did not respond to maximum conventional treatment. Age at referral varied from 11 to 504 hours. Survivors were noted to be significantly younger at referral, but this difference arose from the fact that the two neonates with community acquired infection both died; these infants were older.

Seven of the infants who died had received venoarterial cannulation and one of the remaining infants required conversion from venovenous cannulation to venoarterial ECMO after 250 hours of perfusion. The duration of ECMO varied from 57 to 405 hours (mean 122 hours). Survivors had received ECMO for a significantly shorter period than those who died (mean 104 hours compared with 169 hours). Table 3 shows details of the primary diagnosis and cause of death in the 12 infants who died.

Support was withdrawn in eight patients. In two patients this was because of catastrophic haemorrhage while receiving ECMO. In six patients withdrawal was due to severe cerebral ischaemic damage or haemorrhage noted on cranial ultrasound, or a general deterioration. Four died a few days after apparently successful treatment. All of these four infants received ventilation after ECMO, and in one the death was due to the presenting disorder (severe sepsis), with pneumococcus isolated. Five neonates had lesions reflecting severe cerebral ischaemia, including multiple foci of periventricular leukomalacia, and in two patients there was widespread cystic degeneration; one showed early focal periventricular leukomalacia. Four had haemorrhage within the cerebellum, ranging from a solitary focal lesion $(0.5 \mathrm{~cm}$ diameter in one patient) to complete haemorrhagic necrosis of the cerebellum (two patients). One of these latter patients also had an associated bilateral interventricular haemorrhage. In this patient it was thought that the changes seen were of such an age as to have occurred before the start of ECMO. Three of the infants dying of haemorrhage showed evidence of sepsis at necropsy.

All the neonates had squamous metaplasia of the trachea and evidence of severe lung disease, ranging from thickened alveolar walls due to oedema or fibrosis, or both, with hyaline membrane formation (seven infants), to more severe changes, including large focal pulmonary haemorrhages up to $5 \mathrm{~cm}$ across, desquamation, and necrosis (four infants). The patient who presented with pneumococcal septicaemia had multiple pulmonary abscesses. Table 4 summarises the significant pulmonary findings.

Three neonates showed evidence of myocardial ischaemia, ranging from a minor degree of subendocardial and papillary muscle ischaemia (two infants) to extensive infarction 
Table 4 Pulmonary pathology

\begin{tabular}{|c|c|c|c|c|c|c|}
\hline $\begin{array}{l}\text { Patient } \\
\text { No }\end{array}$ & $\begin{array}{l}\text { Hyaline } \\
\text { membranes }\end{array}$ & Pulmonary haemorrhage & $\begin{array}{l}\text { Interstitial } \\
\text { fibrosis }\end{array}$ & $\begin{array}{l}\text { Active pulmonary } \\
\text { infection }\end{array}$ & $\begin{array}{l}\text { Features of birth } \\
\text { asphyxia }\end{array}$ & Vascular pathology \\
\hline $\begin{array}{r}1 \\
2 \\
16 \\
19 \\
20 \\
21 \\
24 \\
37 \\
38 \\
42 \\
46\end{array}$ & $\begin{array}{l}\text { None } \\
\text { None } \\
\text { Widespread } \\
\text { Widespread } \\
\text { None } \\
\text { None } \\
\text { None } \\
\text { None } \\
\text { Widespread } \\
\text { Widespread } \\
\text { Focal } \\
\text { None }\end{array}$ & $\begin{array}{l}\text { Massive } \\
\text { Widespread } \\
\text { None } \\
\text { Widespread } \\
\text { None } \\
\text { Massive in right lower lobe } \\
\text { None } \\
\text { None } \\
\text { Focal areas } \\
\text { None } \\
\text { None } \\
\text { Mild focal }\end{array}$ & $\begin{array}{l}\text { None } \\
\text { None } \\
\text { Diffuse } \\
\text { None } \\
\text { Diffuse } \\
\text { None } \\
\text { None } \\
\text { Diffuse } \\
\text { Diffuse } \\
\text { Diffuse } \\
\text { None } \\
\text { Focal }\end{array}$ & $\begin{array}{l}\text { None } \\
\text { None } \\
\text { None } \\
\text { None } \\
\text { None } \\
\text { Multiple abscess cavities } \\
\text { None } \\
\text { None } \\
\text { Cytomegalovirus pneumonia } \\
\text { None } \\
\text { Early bronchopneumonia } \\
\text { None }\end{array}$ & $\begin{array}{l}\text { None } \\
\text { Aspirated squames } \\
\text { None } \\
\text { Aspirated squames } \\
\text { None } \\
\text { None } \\
\text { None } \\
\text { None } \\
\text { None } \\
\text { None } \\
\text { Aspirated squames } \\
\text { None }\end{array}$ & $\begin{array}{l}\text { None } \\
\text { Vessel thrombosis with multiple infarcts } \\
\text { None } \\
\text { None } \\
\text { None } \\
\text { None } \\
\text { Early hypertensive changes } \\
\text { None } \\
\text { Large focal areas of necrosis } \\
\text { None } \\
\text { Thrombosis of one medium sized vessel } \\
\text { None }\end{array}$ \\
\hline
\end{tabular}

of the left ventricle (one infant). Two of these were treated by V-A circuits. None of these had evidence of 'myocardial stun' (a term reserved for extreme contractile dysfunction after an ischaemic insult, previously reported in ECMO patients). In one of these neonates there were multiple small foci of myocardial calcification, suggesting an earlier in utero insult.

Three of the neonates dying after apparently successful treatment had a widely patent ductus arteriosus at necropsy and may have had persistent pulmonary hypertension. No specific pathological changes were identified in the pulmonary vessels, however, though it is probable that death occurred too rapidly for these to have developed. One of these infants had had previous cardiac ultrasound ( 24 hours before death), which showed a closed patent ductus. One other infant, who died five days after ECMO (aged 14 days), did have pathological features relating to pulmonary hypertension (thickened pulmonary arterial walls with abundant elastin).

Other pathologies found at necropsy included: (a) evidence of endothelial damage at the site of cannulation; (b) antemortem thrombus (two infants), one of the great cerebral vein and cerebral sinuses (though this had not yet resulted in cerebral infarction), and one of the right common iliac artery - that is, not at sites of cannulation; (c) haemorrhage at the corticomedullary region of the kidney with infarction of the renal medulla (one infant); (d) ulceration of the gastric mucosa with subsequent haemorrhage (one infant); (e) necrotising enterocolitis diagnosed before ECMO and contributing to death (one infant); and (f) iatrogenic pericardial haemorrhage (one infant), the injury having occurred at insertion of a chest drain before referral. Table 5 summarises these findings.

\section{Discussion}

Prolonged venoarterial bypass may have deleterious effects on the lung. In some instances pulmonary oedema, intra-alveolar haemorrhage, and parenchymal necrosis occur within as little as 18 hours and then lead to death from progressive pulmonary hypertension. ${ }^{6}$ The implication in such reports is that reduced pulmonary blood flow is a significant contributory factor in the pathogenesis of the necropsy findings. If this were so then we might expect the more extreme changes in our group to be restricted to the patients who had received a venoarterial cannulation. This was not so, however. Nevertheless, it is possible that some of the lung changes noted here were, at least in part, attributable to bypass in infants already compromised by acidosis and sepsis.

Reperfusion injury is another postulated mechanism by which bypass may contribute to tissue damage - for example, it might be anticipated that infants who are to varying degrees acidotic, hypotensive, hypoxic and poorly perfused would be at risk of widespread free radical production during reperfusion. Such a mechanism has been implicated in the aetiology of myocardial stun. ${ }^{7}$ In this instance we might expect to see differences between

Table 5 Necropsy findings

\begin{tabular}{|c|c|c|c|c|c|}
\hline $\begin{array}{l}\text { Patient } \\
\text { No }\end{array}$ & Myocardial ischaemia & $\begin{array}{l}\text { Patent ductus arteriosis/ } \\
\text { pulmonary hypertension }\end{array}$ & $\begin{array}{l}\text { Haemorrhage } \\
\text { (extrapulmonary) }\end{array}$ & Cerebral ischaemia & Other \\
\hline $\begin{array}{l}1 \\
2\end{array}$ & $\begin{array}{l}\text { No } \\
\text { No }\end{array}$ & $\begin{array}{l}\text { No } \\
\text { No }\end{array}$ & $\begin{array}{l}\text { No } \\
\text { No }\end{array}$ & $\begin{array}{l}\text { No } \\
\text { No }\end{array}$ & $\begin{array}{l}\text { Necrotising enterocolitis, } \\
\text { common iliac thrombus }\end{array}$ \\
\hline $\begin{array}{l}16 \\
19\end{array}$ & $\begin{array}{l}\text { No } \\
\text { Yes, with extensive } \\
\text { calcification }\end{array}$ & $\begin{array}{l}\text { Probe patent duct } \\
\text { Widely patent duct }\end{array}$ & $\begin{array}{l}\text { No } \\
\text { Cerebellar haemorrhagic necrosis, bilat- } \\
\text { eral intraventricular haemorrhage }\end{array}$ & $\begin{array}{l}\text { No } \\
\text { Periventricular leukomalacia, } \\
\text { multiple foci }\end{array}$ & \\
\hline $\begin{array}{l}20 \\
21\end{array}$ & $\begin{array}{l}\text { No } \\
\text { No }\end{array}$ & $\begin{array}{l}\text { Widely patent duct } \\
\text { No }\end{array}$ & $\begin{array}{l}\text { No } \\
\text { Intracerebral and cerebellar, pericardial, } \\
\text { iatrogenic }\end{array}$ & $\begin{array}{l}\text { No } \\
\text { Periventricular leukomalacia } \\
\text { with cystic degeneration }\end{array}$ & $\begin{array}{l}\text { Endothelial damage at site } \\
\text { of cannulation }\end{array}$ \\
\hline 24 & Subendocardial & $\begin{array}{l}\text { Evidence of pulmonary } \\
\text { hypertension }\end{array}$ & No & No & $\begin{array}{l}\text { Cerebral sinus and great } \\
\text { cerebral vein thrombosis }\end{array}$ \\
\hline 37 & No & No & Cerebral & $\begin{array}{l}\text { Periventricular leukomalacia } \\
\text { with cysts }\end{array}$ & \\
\hline 38 & No & No & Minor cerebellar & No & $\begin{array}{l}\text { Endothelial damage at site } \\
\text { of cannulation }\end{array}$ \\
\hline 42 & No & No & Significant cerebellar & 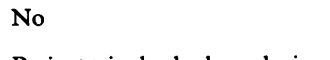 & $\begin{array}{l}\text { Gastric ulceration and } \\
\text { haemorrhage }\end{array}$ \\
\hline 46 & $\begin{array}{l}\text { Subendocardial and } \\
\text { papillary muscle }\end{array}$ & Nor: th & No & $\begin{array}{l}\text { Periventricular leukomalacia, } \\
\text { multiple foci }\end{array}$ & \\
\hline 49 & No & Widely patent duct & No & $\begin{array}{l}\text { Periventricular leukomalacia, } \\
\text { cortical atrophy }\end{array}$ & \\
\hline
\end{tabular}


those patients who had received venovenous and venoarterial cannulation as these modes of cannulation differ in their impact on haemodynamics and oxygen delivery. Venoarterial cannulation, at high blood flow rates, reduces the pulsatility of the systemic arterial circulation and creates high arterial oxygen tensions. Venovenous cannulation raises the mixed venous oxygen content and, in the face of negligible native pulmonary function, the patient is perfused with a pulsatile circulation of blood with a lower oxygen tension. Systemic oxygen delivery in such circumstances is assured by a compensatory increase in native cardiac output. Myocardial perfusion is probably best during venovenous as opposed to venoarterial ECMO as there is evidence that coronary blood flow is still largely derived from pulmonary venous return irrespective of cannulation. ${ }^{8}$ The oxygen content of this blood is higher during a venovenous perfusion. In this context it is interesting to note that two of the three cases of myocardial infarction occurred during a venoarterial circuit.

As ECMO includes heparinisation, it might be expected that complications will arise relating to haemorrhage. Indeed, although significant haemorrhage was limited to five patients in this series, some degree of haemorrhage occurred in $50 \%$ of the deaths at varying sites. No statistically significant difference could be found between those with and without haemorrhage, though concomitant sepsis was implicated in $60 \%$ of patients with extensive haemorrhage. It is known that prolonged acidosis renders infants at greater risk of haemorrhage and therefore more susceptible to heparinisation. Haemorrhagic complications in ECMO patients have been widely reported $^{9}$ and associated with low birth weight, prematurity, prolonged acidosis, cardiac arrest, and hyoxia. ${ }^{10-12}$ Our results accord with these observations.

Cerebellar haemorrhages occurred in four patients and are well recognised as occurring in anoxic premature infants, but are relatively unusual in more mature infants such as those in this study. The pathogenesis of cerebellar haemorrhage is poorly understood. One hypothesis considered pressure effects on the cerebral circulation due to facemask attachments, ${ }^{13}$ though this theory has not been substantiated. It is more likely that the frequency of haemorrhages in the cerebellum in premature infants reflects the poorly formed capillary bed in this region. ${ }^{14}$ Even in more mature infants there may still be some selective vulnerability to anoxia in this region. There was no obvious correlation between the occurrence of cerebellar haemorrhages and initial $\mathrm{pH}$, period of illness, or gestational age. Infants receiving ECMO are nursed in a supine position with the head turned to the left; it may be that the altered circulation during ECMO, combined with the supine position and heparinisation, increases the susceptibility at this point.

ECMO has been used successfully in the treatment of persistent pulmonary hypertension of newborn infants. ${ }^{15}$ Indeed, survival rates of $85 \%$ of this disorder in the registry of the Extracorporeal Life Support Organisation are as high as $90 \%$ at some centres. ${ }^{1}$ This pathophysiological state can occur in isolation or as a secondary complicating feature in patients selected for ECMO treatment. It is possible that the non-responders will include a proportion of unusual diagnoses - for example, alveolar-capillary dysplasia ${ }^{16}$ or congenital pulmonary alveolar proteinosis ${ }^{17}$ - in addition to those infants referred too late for successful treatment by any means. As our knowledge of these entities improves, we may be able to predict outcome by a lung biopsy before ECMO, as has been advocated. ${ }^{18} 19$ No unexpected pulmonary diagnoses were detected in the four patients with persistent pulmonary hypertension who died in this series.

Many of the pathological changes observed were far more extensive than are usually seen in similar infants dying after intensive care - for example, marked thickening and fibrosis of alveolar walls, extensive haemorrhage in lungs and brain, and the extent and severity of the ischaemic brain damage. In addition to the severity of presentation this may be because ECMO provides a means of supporting these infants beyond the time when death would have otherwise occurred, thus allowing progression of the pathological findings. To produce accurate discriminatory data it would be necessary to compare pathological findings in a study of patients whose treatment had been subject to random allocation. In this context, pathology has much to contribute to the delineation of the role of ECMO in neonatal practice.

We thank all clinicians and pathologists at Leicester Royal Infirmary, Groby Road Hospital, Leicester and the Royal Hospital for Sick Children, Edinburgh for information abou the cases reported in this paper.

1 Bartlett RH. Extracorporeal life support for cardiopulmonary failure. Curr Probl Surg 1990; 27: 621-705. 2 Arensman RM, Cornish JD. Extracorporeal life support. Boston: Blackwell Scientific, 1993.

3 Hill JD, O'Brien TG, Murray J, et al. Prolonged extracorporeal membrane oxygenation for acute post-traumatic respiratory failure (shock-lung syndrome). Use of the Bramson membrane lung. N Engl f Med 1972; 286: 629-34.

4 Sosnowski AW, Bonser SJ, Field DJ, Graham TR, Firmin RK. Extracorporeal membrane oxygenation. BMF 1990; 301: 303-4.

5 Pearson GA, Field DI, Firmin RK, Sosnowski AS. UK experience in neonatal extracorporeal membrane experience in neonatal extracorporeal

6 Koul B, Willen H, Sjöberg T, Wetterberg T, Kugelberg J, Steen S. Pulmonary sequelae of prolonged total venoarterial bypass: evaluation with a new experimental model. Ann Thorac Surg 1991; 51: 794-9.

7 Bolli R, Jeroudi MO, Patel BS, et al. Marked reduction of free radical generation and contractile dysfunction by antioxidant therapy begun at the time of reperfusion. Evidence that myocardial 'stunning' is a manifestation of reperfusion injury. Cir Res 1989; 65: 607-22.

8 Kinsella JP, Gerstmann DR, Rosenberg AA. The effect of extracorporeal membrane oxygenation on coronary perfusion and regional blood flow distribution. Pediatr Res perfusion and re

9 Cilley RE, Zwischenberger JB, Andrews AF, Bowerman $\mathrm{RA}$, Roloff DW, Bartlett RH. Intracranial haemorrhage during extracorporeal membrane oxygenation in neonates. Pediatrics 1986; 78: 699-704.

10 Weber TR, Westfall SH, Sotelo C, Vogler CA, Tracy T. A clinico-pathological study of nonsurvivors of newborn ECMO. $\mathcal{F}$ Pediatr Surg 1993; 28: 135-7.

11 Watson JW, Brown DM, Lally KP, Null D, Clark R Complications of extracorporeal membrane oxygenation in neonates. South Med F 1990; 83: 1262-5.

12 Bui KC, LaClair P, Vanderkerhove J, Bartlett RH. ECMO in premature infants. Review of factors associated with mortality. ASAIO Trans 1991; 37: 54-9.

13 Pape KE, Armstrong DL, Fitzhardinge PM. Central nervous system pathology associated with mask ventilation in the very low birth weight infant: a new etiontilation in the very low birth weight infant: a new etiology fo 
14 Pape KE, Wigglesworth JS. Haemorrhage, ischaemia and the perinatal brain. London: Heinemann, 1979.

15 Anonymous. Persistent foetal circulation and extracorporeal membrane oxygenation [Editorial]. Lancet 1988; ii: 1289-91.

16 Cullinane C, Cox PN, Silver MM. Persistent pulmonary hypertension of the newborn due to alveolar capillary dysplasia. Pediatr Pathol 1992; 12: 499-514.

17 Moulton SL, Krous HF, Merritt TA, Odell RM, Gangitano E, Cornish JD. Congenital pulmonary alveolar proteinosis: failure of treatment with extracorporeal life

support. $\mathcal{F}$ Pediatr 1992; 120: 297-302.
18 Hill DJ, De Leval MR, Fallat RJ, et al. Acute respiratory insufficiency. Treatment with prolonged extracorporeal oxygenation. $f$ Thorac Cardiovasc Surg 1972; 64: 551-62.

19 Bartlett RH, Gazzaniga AB, Fong Sw, Burns NE. Prolonged extracorporeal cardiopulmonary suppor in man. $f$ Thorac Cardiovasc Surg 1974; 68: 918-32. 